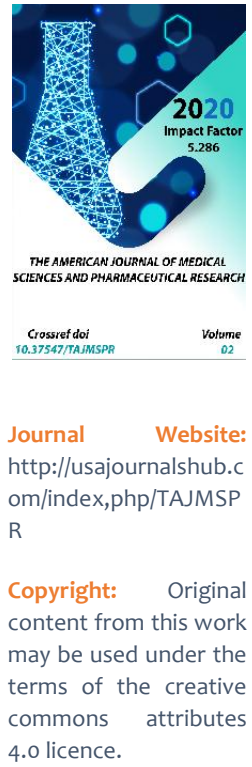

\title{
A New Source Of Biologically Active Substances Used In The National Economy And Medicine
}

\author{
Yusupova S.S. \\ Candidate Of Chemical Sciences, Associate Professor, The Department Of Medical And \\ Biological Chemistry, Samarkand State Medical Institute, Uzbekistan. \\ Holmurodova D.K. \\ Phd, Head Of The Department Medical And Biological Chemistry, Samarkand State Medical \\ Institute, Uzbekistan. \\ Kiyamova D.Sh. \\ Assistant, The Department Of Medical And Biological Chemistry, Samarkand State Medical \\ Institute, Uzbekistan
}

\section{ABSTRACT}

The methodology for obtaining biologically active substances is given: phytol, isophytol, tokferol, phylloquinone and their application in medicine and the national economy.

\section{KEYWORDS}

Silkworm (HTS), chlorophyll, carotene, riboflavin, folic acid, phytol, isophotal, tocopherol, phylloquinone.

\section{ABBREVIATIONS}

BAS - biologically active substances, HTS - a selection of the silkworm, 


\section{INTRODUCTION}

The problems of renewable raw materials for the production of biologically active preparations used in the national economy and medicine are one of the most important tasks of chemical technology. According to the results of our studies, it was found that several valuable products such as chlorophyll, porphyrins and their metal complexes, semiproducts for the synthesis of vitamins E, K, carotene, bioflavonoids of lipids, etc. can be obtained from the isolation of silkworms (HTS). This article describes the use of HTS as a source for the production of biologically active substances.

Mulberry caterpillars, eating a mulberry leaf, receive a rich assortment of various biologically active substances. Along with chlorophyll, the body of mulberry worm receives vitamins: carotene (provitamin $A$ ), $B$ vitamins, ascorbic acid (vitamin $C$ ), riboflavin, folic acid, various organic acids, etc. To date, sufficient information has been accumulated on the content of these compounds in mulberry leaves at various vegetation dates at species and grade levels. A fairly complete image of these data is given in the monograph by G.M. Talyshinsky [1]. The content of vitamins in the leaves of vitamins depends on the type of plants, variety and phase of their development. The works $[2,4,5]$ show that the amount of ascorbic acid in the mulberry leaf during its ripening increases to a maximum by the time of fruiting of the mulberry tree $(\sim 0,400 \mathrm{mg}$ in $100 \mathrm{~g}$ of the fresh leaf), i.e. at the $V$ age of the silkworm caterpillars of spring feeding. Then, the entire period of formation and ripening of mulberries is characterized by a decrease in the carotene content in the mulberry leaf of all varieties is observed during the fruiting period of the plant ( $0.9 \mathrm{mg}$ per $\mathrm{kg}$ of the fresh leaf) and will remain at a close level until September, then drops sharply. It was also found that when mulberry leaves mature, the content of thiamine, riboflavin, is constant.

\section{MATERIALS AND METHODS}

The silkworm larva absorbs vitamins and organic substances necessary for its growth and development from the feed, releasing their excess with expiration. On a qualitative level, it has been established that HTS contains carotenoids, $B$ vitamins, vitamin $P$ and other useful compounds. In this article, we considered it necessary to dwell in more detail on the possibility of isolating from the HTS those biologically active substances that are of significant practical interest.

Phytol (formula 1) and isomeric isophotal (2) are of the utmost considerable attention of researchers. This is due to the fact that they are used in the synthesis of vitamins $\mathrm{E}$ and $\mathrm{KI}$ [3], which are widely used in medical practice and veterinary medicine. Lack of a-tocopherol or vitamin E (3) in the body, which is a condensation product of trimethylhydroquinone with phytol, causes muscle tissue atrophy in animals and infertility. In the case of vitamin $\mathrm{KI}$ or phylloquinone (4), the phenolic residue is bound to the naphthoquinone nucleus.

Vitamin $\mathrm{KI}$ is used in therapy as a drug that accelerates blood clotting. Both vitamins are used in livestock and poultry farming as part of premixes. 


\section{1 formula.}

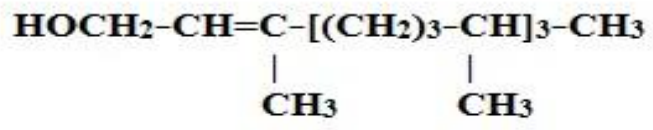

1

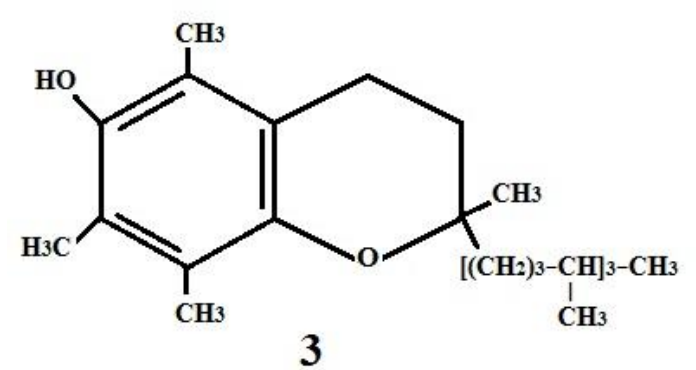

The ever-increasing demand of various branches of the national economy for these vitamins cannot be met by natural sources in which they are contained in relatively small quantities ( 40- $70 \mathrm{mg} \%$ ) [3]. Also, their separation from the products of processing of natural raw materials requires complex methods of purification from related impurities. Known industrial methods for the synthesis of racemic forms of vitamins $E$ and $\mathrm{KI}$ are based on the use of isophotal, synthesized, in turn, according to a multistage scheme [2]. However, this does not exclude the prospect of replacing isophotal (2) with (1), which will allow the synthesis of optically active vitamins E (3) and $\mathrm{K}_{1}$ (4), which exhibit a greater therapeutic effect compared

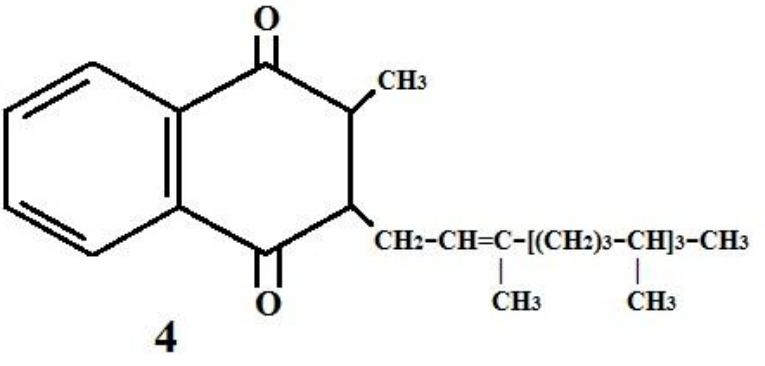

to the corresponding racemates [2]. The feasibility of a particular alcohol component in the synthesis of vitamins is determined not only by the availability of phytol or isophotal but also by their cost. As a rule, the source of phytol is chlorophyll of various plants, which for this purpose is either subjected to alkaline hydrolysis or treated with the enzyme chlorophyllase. As a feedstock, in this case, nettle and mint are offered. The published methods differ not only in the conditions of saponification of plant chlorophyll but also in various methods of isolating the desired compound. The phytol was first obtained in 1906, and its structure was installed in 1928 by T. Fitter and K. Lovenberg [1]. In 1939, P. Karer and B. Ringen proposed a method for 
synthesizing phytol [4]. However, synthetic phytol did not find industrial use due to the complexity of its synthesis, as well as the relatively low yield of the product. Therefore, in the future, the main attention of researchers was paid both to the development of methods for its production from natural raw materials and the search for new sources suitable for its isolation.

Method of vitamin $E$ synthesis based on phytol. A mixture of $0,192 \mathrm{~g}$ of $98.5 \%$ or 0,190 $\mathrm{g}$ of $100 \%$ (50*10-4 mole) tetra-methyl hydroquinone and $0.37 \mathrm{~g}$ of aluminosilicate in $5 \mathrm{ml}$ of nonane was heated to boiling under stirring under nitrogen flow and water adsorbed on the catalyst with solvent vapours was distilled off for 0.5 hours into a DeanStark nozzle pre-filled with solvent. Then, a solution of $0.38 \mathrm{~g}$ of phytol $(5 * 10-4 \mathrm{mmol})$ in $5 \mathrm{ml}$ of nonane was added to the boiling mixture in 0.5 hours under conditions of the continuous distillation of water formed during the reaction with solvent vapour. After completion of the condensation process (control of TLC in the hexane-ether system (2:1), developer - iodine vapour, $\mathrm{Rf}$ vitamin $\mathrm{E}=$ $0.53)$, the reaction mass was cooled to $200 \mathrm{C}$ and filtered through Schott filter No. 4. The separated catalyst was washed with nonane $(3 \times 10 \mathrm{~mL})$. The combined filtrates were evaporated in vacuo and the technical vitamin E was purified on a column filled with $L$ 40/100 silica gel as eluent using hexane. After chromatography, $0.5 \mathrm{~g}$ of vitamin $\mathrm{E}$ with a content of $98.3 \%$ was obtained according to GLC. The yield of the product is $92.1 \%$ of the theoretical. Thus, according to our technology, HTS can be effectively used by processing them, isolating protein extraction cake, chlorophyll, which in turn can be processed into pheophorbide and phytol, fatty acids and possibly other biologically active substances.
As a result of our research, it was found that the expression of silkworm caterpillars is a rich source of a large number of various biologically active substances and, above all, porphyrins, which not only carry out the most important biological functions in wildlife but also found wide application in technology and medicine. The search for applications of natural porphyrins and their derivatives is primarily concentrated in the field of medicine. This is primarily due to their low toxicity to living tissues and biological media. Also, chlorophyll has a powerful antioxidant effect and, due to this, protects cells from the detrimental effect of constantly formed radicals from destruction by electric charges on cell membranes, hydrogen ions in the centres of inflammation [5-8].

Currently, chlorophyll-containing drugs (extracts, tinctures, infusions from herbs and plant leaves) occupy a significant place in the arsenal of drugs. Hundreds of works have been published in the literature on the study of various aspects of the effects of chlorophyll preparations on the body of animals and humans. In veterinary medicine, chlorophyll preparations improve the reproductive abilities of agricultural animals, accelerate their growth and development, and increase resistance to infections. In humans, chlorophyll-containing drugs were successfully used in the complex treatment of infectious diseases [8,9], alcoholism [5], in the photodynamic therapy of malignant tumours $[3,5-6.8]$.

The development of drugs and other biologically active agents based on chlorophyll derivatives is, apparently, one of the most promising applied areas in the problem of using profirins. It has now been established that: 
1. Several diseases, such as anaemia, cancer, neuropsychiatric disorders, poisoning with lead and some organic substances, certain skin diseases, radiation injuries and other pathological abnormalities, are accompanied by a significant violation of porphyrin metabolism in the body. With porphyrins, lupus erythematosus, these disorders play a decisive role in the pathogenesis of diseases.

2. Exogenous porphyrins are able to accumulate in rapidly regenerating tissues. The fluorescence of the molecule of individual porphyrins makes them a convenient object for testing in biological media and tissues.

3. The photodynamic action of porphyrins served as the basis for the use of compounds in the photochemotherapy of tumours and other diseases.

4. It was found that some natural and synthetic porphyrins have significant catalytic and enzymatic activity, due to which they can act as activators or sensitizers of processes.

5. And, finally, porphyrins have the property of modifying radiation damage to biological objects.

A significant number of works are devoted to the use of porphyrins in oncology.

Hematoporphyrin and tetrasulfotetraphenylporphin were premixed for tumour diagnostics using the selective tropism of these compounds and the ability to fluoresce in tissues. The metal complexes of hematoporphyrin and protoporphyrin have been studied as therapeutic agents that inhibit the growth of cancer cells in cancer of the lungs, stomach, rectum, etc. Recent publications have noted the promise of coproporphyrins, which have a high therapeutic index. Research on the treatment of certain types of malignant tumours by the combined use of porphyrins and visible and laser radiation is of great practical importance.

\section{CONCLUSION}

In conclusion, the following constants may be used: The brief list of applications of porphyrins shows that the need for these compounds is great, and the search for new cheap sources of these compounds is undoubtedly relevant. In accordance with the principles and technology proposed by us, this problem is solved in two directions. On the one hand, research is developing in the field of the scientific foundations of the technology for the isolation of chlorophyll and the products of its modification from HTS.

On the other hand, new applications of chlorophyll processing products, in particular, pheophorbides and other porphyrins, are being sought.

\section{REFERENCES}

1. Talyshinsky, G.M. (1990). Biochemistry of the polyploid mulberry leaf. Baku: Elm. p. 132.

2. Lamm G. Ya., Khamidova Zh. B., Doncheva E. F., Parshiev B. A. (1991). Silk. No 1, p. 14.

3. Tarasevich, M. R., Radyushkina K.A., Bogdanovskaya V.A. (1991). Elektrokhimiya porfirinov. Moskva, Nauka. (3). p. 312.

4. Cheng, L., Richter-Addo, G. B., Guilard, R., Smith, K., \& Kadish, K. M. (2000). in The Porphyrin Handbook, Eds K. M. Kadish, KM Smith, and R. Guilard, Acad. Press., (4), p. 221. 
5. Moiseeva, M. V., \& Mikhailets, T. A. (2000). Primenenie proizvodnykh khlorofilla $\mathrm{v}$ meditsine. Izuchenie $\mathrm{i}$ primenenie lechebnoprofilakticheskikh preparatov na osnove prirodnykh biologicheski aktivnykh veshchestv. Pod red. VG Bespalova i VB Nekrasovoi. SPb.: Eskulap.

6. Mironov, A. F. (1998). Razrabotka sensibilizatorov vtorogo pokoleniya na osnove prirodnykh khlorofillov. Ros. khim. zhurnal, 1(5), 23-26.

7. Lomova T.N., Berezin B.D. (1993). Koordinats. Khimiya. 19.(3). p. 171.

8. Nekrasova V.B., Nikitina T.V., Kurnygina V.T. (2000). Biologicheski aktivnye veshchestva khvoi sosny i eli ikh primenenie $v$ meditsine. Izuchenie $i$ primenenie lechebno profilakticheskikh preparatov na osnove prirodnykh biologicheski aktivnykh veshchestv. SPb: «Eskulap», p.92.

9. Boydadayev, M., Negmatov, S., Polvonov, A., \& Khoshimzhon, A. (2020). The dependence of physicomechanical properties of wood-plastic composite plate materials from the content of polymer binder. Journal of Critical Reviews, 7(2), 46-48. 